\title{
scripted
}

Volume 15, Issue 2, October 2018

\section{Brexit and the Unitary Patent Package: A Further Compromised Future?}

\author{
Aisling McMahon* \\ (ㄷ) (1) $(9)$ \\ (C) 2018 Aisling McMahon \\ Licensed under a Creative Commons Attribution-NonCommercial- \\ NoDerivatives 4.0 International (CC BY-NC-ND 4.0) license
}

DOI: $10.2966 /$ scrip.150218.175

\begin{abstract}
Developing a unitary patent system for Europe has been debated for over 50 years but never achieved. Nonetheless, a unitary patent package (UPP) for the current $25 \mathrm{EU}$ Member States who wish to participate is now within grasp. However, as this system neared completion, the UK voted to leave the EU by referendum on 23 June 2016. The UK subsequently triggered Article 50 TEU on 29 March 2017 commencing its withdrawal from the EU (Brexit) in a process expected to take two years. Beyond the broader legal and political questions which Brexit gives rise to, it raises a key question for patent lawyers, namely, whether, and under what circumstances, the UK can continue to participate in the Unified Patent Court (UPCt) system and European Patent with Unitary Effect (EPUE) when it leaves the EU?
\end{abstract}

In November 2016, despite the Brexit vote, the UK government confirmed its intention to join the Agreement on the Unified Patent Court (AUPC) and subsequently ratified the AUPC on 26 April 2018. However, this article argues that in light of the complex relationship the UPCt has with the EU, including, the primacy of EU law in the operation of the UPCt and links between the UPCt and the Court of Justice of the European Union (CJEU), 
joining the AUPC at this point is a curious move and one which is inconsistent with the UK's previous more general statements on Brexit. In particular, in February 2017 Theresa May while outlining key facets of Brexit stated that the UK would not be subject to the jurisdiction of the CJEU once it leaves the EU. The article highlights the difficulties with ameliorating this position with the UK's continued participation in the UPP post-Brexit. It argues that Brexit will likely sound the death knell for the UK's membership of EPUE. Moreover, although UK participation in the UPCt seems more likely there remains considerable challenges to tackle in this respect.

Furthermore, the question mark that exists over the UK's participation in the UPCt and EPUE post-Brexit has attendant consequences for the general feasibility of the UPP. Accordingly, this article argues that instead of focusing on how to keep the UK within the currently devised system, Brexit provides further impetus to pause and consider whether the current proposal is still worthwhile given that it will create a more complex and fragmented European patent landscape at the supranational level. Instead, this article echoes calls that a better solution would be to consider ways to modify the current system or redesign a new system to include not just the UK but also other European Patent Convention states which are not in the EU.

\section{Keywords}

Unitary Patent; Brexit; European Patent Convention; United Kingdom

* Lecturer, Department of Law, National University of Ireland Maynooth, Ireland, aisling.mcmahon@mu.ie 


\section{Introduction}

Discussions about developing a unitary patent for Europe have been ongoing for the last 50 years, ${ }^{1}$ but despite several false starts, unitary patent protection for all European countries has never been accomplished. Nonetheless, a unitary patent package (UPP) - which includes a Unified Patent Court (UPCt) and a European patent with unitary effect (EPUE) - for the twenty-five EU Member States who wish to participate in it seemed until recently almost within grasp. ${ }^{2}$ The relevant legal instruments were agreed upon by participating EU Member States in 2012,33 and all that remains for this system to commence is for the Agreement on the Unified Patent Court (AUPC) to be ratified by a sufficient number of parties. ${ }^{4}$ This requires ratification from 13 of the participating EU Member States, which must include the UK, Germany, and France. ${ }^{5}$

The ratification process initially progressed well, and at the time of writing, ${ }^{6}$ there are sixteen ratifications, including France. The United Kingdom

1 See Luke McDonagh, "Exploring perspectives of the unified patent court and unitary patent within the business and legal communities" (UK IPO, 2014) and Aurora Plomer, "A unitary patent for a (Dis)United Europe: the long shadow of history" (2015) 46(5) International Review of Intellectual Property and Competition Law 508-533.

2 The 25 participating States are as follows: Austria, Belgium, Bulgaria, Cyprus, Czech Republic, Germany, Denmark, Estonia, France, United Kingdom, Greece, Hungary, Italy, Ireland, Lithuania, Luxembourg, Latvia, Malta, Netherlands, Portugal, Romania, Sweden, Finland, Slovenia, and Slovakia. All current EU States except Croatia, Poland, and Spain. This is discussed further below. Correct at the time of writing (May 2018).

3 Regulation 1257/2012 of the European Parliament and of the Council of 17 December 2012 implementing enhanced cooperation in the area of the creation of unitary patent protection, OJ L 361/1 of 31.12.2012 (Regulation 1257/2012); Council Regulation 1260/2012 implementing enhanced cooperation in the area of the creation of unitary patent protection with regard to applicable translation arrangements (Regulation 1260/2012). Council Agreement on a Unified Patent Court (2013/C 175/01). See also Decision 2011/167/EU which allowed for the system of enhanced co-operation amongst EU States necessary for the package to go ahead.

4 Art. 18(2) Regulation 1257/2012.

5 Select Committee of the Unified Patent Court, "An Enhanced European Patent System" (2014), available at https://www.unified-patent-court.org/sites/default/files/enhancedeuropean-patent-system.pdf (accessed 1 February 2018), p. 19.

6 Correct at the time of writing (May 2018). 
also recently ratified the AUPC in April 2018, however, Germany has not done so. ${ }^{7}$ Moreover, in the context of these two latter States, since 2012, two changes occurred which potentially jeopardise or at the very least raise important questions for the future operation and desirability of the planned UPP system, namely: (1) the UK voted to leave the EU in June 2016 (Brexit); and (2) a German constitutional complaint has been submitted against the ratification of the AUPC which is still ongoing. ${ }^{8}$

This article focuses specifically on the former development, examining the effect of Brexit on the UK's participation in the planned EPUE and particularly in the UPCt system. It primarily examines the UK's participation in the UPCt system post-Brexit because the UK has given commitments on this and it is legally possible given that the UPCt is based on an international agreement, however, participation in the EPUE, as will be demonstrated is unlikely given that it is an EU right and not an international right. ${ }^{9}$ Nonetheless, even in terms of the UPCt system, this article will argue that despite the UK announcing in November $2016^{10}$ that it will remain part of the AUPC regardless of Brexit and its

Correct at the time of writing (May 2018).

8 Correct at the time of writing (May 2018). This is case number 2 BvR 739/17. See: German complaint against Unified Patent Court Agreement on FCC decision list for 2018' (Kluwer Patent Blogger, 21 February 2018) http://patentblog.kluweriplaw.com/2018/02/21/germancomplaint-unified-patent-court-agreement-fcc-decision-list-2018/ “German complaint threatens future Unitary Patent system" (Kluwer Patent Blog, 2 November 2017), available at http://patentblog.kluweriplaw.com/2017/11/02/german-complaint-threatens-future-unitarypatent-system/ (accessed 14 January 2018); “Breaking: German Constitutional Court stops implementing legislation for Unitary Patent Package" (IPKat Blog, 12 June 2017), available at http://ipkitten.blogspot.ie/2017/06/breaking-german-constitutional-court.html (accessed 1 February 2018). See also Manuel Rey-Alvite Villar and Lisa Schneider, "German Constitutional Court puts ratification of the UPC Agreement on hold" (Bristows UPC Blog, 13 June 2017).

9 See also Luke McDonagh, “UK Patent Law and Copyright: Law after Brexit Potential Consequences" British Institute for Comparative and International law, Brexit: The International Legal Implications, Paper No. 3 (November 2017), p. 7.

10 UK Government Press Release, "UK signals green light to Unified Patent Court Agreement" (28 November 2016), available at https://www.gov.uk/government/news/uk-signals-green- 
subsequent ratification of the AUPC in April 2018, uncertainties and inconsistencies remain in this context. In particular, this move disregards the intertwined relationship the UPCt has with the EU, including the primacy of EU law in the UPCt's operation and the links between the UPCt and the Court of Justice of the European Union (CJEU). This is politically problematic for the UK's involvement in the UPCt, as it is inconsistent with the government's previous general statements on Brexit. Indeed, three months after the UK announced its continued intention to join the UPCt system Theresa May in her Prime Minister's address outlining key facets of Brexit stated that the UK will not be subject to the jurisdiction of the CJEU once it leaves the EU. ${ }^{11}$ This was subsequently reiterated in the UK government's whitepaper on Brexit in February 2017.12

Thus, it is difficult, if not impossible, to ameliorate the government's stated position on the UK's relationship with the CJEU post-Brexit, with its participation in the UPCt system. ${ }^{13}$ Moreover, even if the UK were to modify this position and accept the CJEU's jurisdiction in this context post-Brexit which will be required to participate in the UPCt system, it is not clear that the UK's membership of the UPCt - as a non-EU Member State - would be compatible

light-to-unified-patent-court-agreement (accessed 6 December 2017); see also “EPO President welcomes UK's decision to ratify UPC Agreement" (29 November 2016), available at https://www.epo.org/news-issues/news/2016/20161129.html (accessed 1 February 2018).

11 See Theresa May, Prime Minister's Speech, “The government's negotiating objectives for exiting the EU: PM speech" (17 January 2017), available at https://www.gov.uk/government/speeches/the-governments-negotiating-objectives-forexiting-the-eu-pm-speech (accessed 1 February 2018), in which she stated that: "So we will take back control of our laws and bring an end to the jurisdiction of the European Court of Justice in Britain".

12 HM Government, Whitepaper, “The United Kingdom's exit from and new partnership with the European Union" (February 2017) available at https://www.gov.uk/government/publications/the-united-kingdoms-exit-from-and-newpartnership-with-the-european-union-white-paper (accessed 1 February 2018).

13 See also Ingve Björn Stjerna, “'Unitary patent' and court system - The British ratification paradox" (2 February 2017), available at http://www.stjerna.de/files/Unipat UKratification.pdf (accessed 1 February 2018), pp. 4-5. 
with EU law. As will be demonstrated, other non-EU Member States which are party to the European Patent Convention (EPC) but not in the EU are not currently allowed to sign the AUPC to take part in the UPCt system. Therefore, it remains to be seen whether the AUPC can be modified to accommodate the UK's peculiar position as a state which is currently in the EU but is shortly set to leave it. If it is modified in this way, then it would also be somewhat difficult to justify that the UK would be allowed to participate because it happened to be in the EU at the ratification date, but left the EU after this, whereas other EPC States not in the EU are not allowed participate in the AUPC and therefore any element of the UPP.

Regard must also be had to the CJEU's Opinion $1 / 09^{14}$ on a previous iteration of the unified patent system involving non-EU Member States which was rejected as incompatible with EU law. An analysis of this opinion highlights the precarious nature of the UK's position in the UPCt and provides lessons on what measures the UK would arguably have to adopt to try to ensure its postBrexit participation in the UPCt system is compatible with EU law. However, this article argues that: (1) as noted, politically, the move is inconsistent with the UK government's stated general position on Brexit, as the UK would need to remain subject to the CJEU's jurisdiction in this context; (2) even if it does so, the UK would also have to meet additional requirements under Opinion 1/09 to safeguard EU law; and (3) even if all of these protections were guaranteed, the compatibility under EU law of the UK's participation in the UPCt system postBrexit could still subsequently be challenged. In effect, the article will demonstrate that the UK's future position in the UPCt system is still on precarious footing.

14 Opinion 1/09 [2011] ECR I-1137. 
These arguments are important more generally for the future of the UPCt system, because the desirability of the already compromised UPP would be further undermined if the UK is not a participant in the UPP (the UPCt or EPUE elements). From an economic and practical perspective questions would arise given that the UK currently has one of the highest number of patents granted in the EU each year. Furthermore, to get the UPP to this stage has involved making one compromise after another to the extent that the current proposal is barely recognisable from earlier proposals which initially involved creating a unitary patent system for all 38 EPC Contracting States or when this failed, a unitary patent system for all EU Member States. The current attempts to mould the proposed UPP plans to allow the UK to remain part of the UPCt system postBrexit provide a further example of the level of compromise which states have been willing to go to in order to bring the UPP into effect. This acceptance of compromise is arguably motivated from the fact that similar proposals for a European unitary patent system have failed before, and States may wish to get this one in place and deal with issues arising afterwards. However, we should be asking if the final product in its current form is worthwhile or more specifically, whether such continued compromises are desirable, because the UPCt system and EPUE which will result will create a multi-layered and further fragmented European patent system at the supra-national level. As will be demonstrated, this is far from the ideal of unitary patent protection initially proposed. These efforts may also be for naught as the intricate compromises required to keep the UK in the UPCt system could subsequently be challenged and held incompatible with EU law.

For these reasons, this article argues that instead of creating further compromises to bring the currently proposed system into effect resulting in a further fragmented supra-national patent landscape in Europe, Brexit and the difficulties posed for UK participation in the UPP provide another opportunity 
to re-evaluate the current proposals. Rather, than amending the AUPC to keep the UK as a party to it post-Brexit, this article echoes wider calls for there to be a reconsideration of the UPP proposal or as Jaeger has called for a "reset and go". ${ }^{15}$ In short, the Brexit challenge provides even greater impetus to reconsider and redevelop a unitary patent package to include all EPC Contracting States. ${ }^{16}$ This would achieve unitary protection for a broader range of states and reduce the complex and overlapping avenues for protection that will occur under the currently proposed scheme. ${ }^{17}$

In making these arguments, the article is structured as follows: part two sets the discussion in context by providing an overview of the current "European" patent system under the EPC and the changes proposed by the currently designed UPP. Following this, parts three and four highlight two remaining roadblocks for the UK's participation in the UPCt system in light of Brexit. Part three considers the role of the CJEU in the operation of the UPCt, whilst part four examines whether only EU Member States can participate in the UPCt system proposal for it to be compatible with EU law assessing the likely impact of Opinion $1 / 09^{18}$ on this question in the UK context post-Brexit. Following this, part five demonstrates the significant implications which UK nonparticipation in the UPCt system or EPUE post-Brexit would have both for the UK itself and more generally, its implications in terms of the desirability of the unitary patent system. Finally, part six concludes by reiterating the uncertainties

15 Thomas Jaeger, "Reset and Go: The Unitary Patent System Post-Brexit" 48(3) International Review of Intellectual Property and Competition Law 254-285.

16 See ibid.; Tuomas Mylly, "Hovering between Intergovernmentalisam and Unionization: The Shape of Unitary Patents" (2017) 54 Common Market Law Review 1381-1426.

17 These are discussed in Aisling McMahon, "An Institutional Examination of the Implications of the Unitary Patent Package for the Morality Provisions: A Fragmented Future Too Far?" (2017) 48(1) International Review of Intellectual Property and Competition Law 42-70.

18 Opinion 1/09 [2011] ECR I-1137. 
and inconsistencies around the UK's membership of the currently envisaged UPP post-Brexit. It is likely that Brexit will sound the death knell for the UK's participation in the EPUE and without significant changes Brexit will also pose serious difficulties for its future participation in the UPCt system. ${ }^{19}$ More generally, however, Brexit reignites questions about the desirability and economic efficiency of the currently proposed UPP.

\section{The current "European" patent system and planned Unitary Patent Package (UPP)}

The European Patent Convention (EPC) was adopted in 1973 and has thirty-eight Contracting States including all EU Member States. This intergovernmental treaty provides for a single application route to obtaining a patent in the thirtyeight Contracting States. Applicants apply to the European Patent Office (EPO) using the classical European Patent (EP) route specifying which EPC states they want the patent granted in. If granted applicants receive a bundle of national patents in the states applied for. However, despite the single application route for patent grant, the post-grant life of the patents is generally considered separately in each of the national states where the patent was granted in. Accordingly, this leaves open the possibility of national divergence on patents across the 38 EPC states. ${ }^{20}$ Given that the EPC is not an EU legal instrument and instead is an international treaty concluded outside the EU system, the UK's position in this system will remain unchanged post-Brexit. However, an issue

19 It has been argued that Brexit could be the impetus required for a rethinking of the AUPC, to adopt an alternative model for the UPCt which would allow non-EU States to be party to it: see Thomas Jaeger, "Guest Post: Is Brexit Breaking the Unitary Patent?" (IPKat Blog, 11 July 2016), available at http://ipkitten.blogspot.ie/2016/07/guest-post-is-brexit-breakingunitary.html (accessed 1 February 2018), and Jaeger, "Reset and Go", supra n. 15.

20 See discussion in Luke McDonagh, European Patent Litigation in the Shadow of the UPC (Elgar Publishing, 2016), pp. 12-17. 
that will need to be resolved ${ }^{21}$ is that once the UK leaves the EU, the Brussels I Regulation $^{22}$ on cross border jurisdiction, recognition, and enforcement of judgments in civil and commercial matters will cease to apply. This is problematic for patents because, for instance, UK judgments on infringement/invalidation of patents would not be valid outside the UK, and this will need to be addressed, for example by UK accession to the Lugano Convention..$^{23}$

The proposed Unitary Patent Package (UPP) - which is ancillary to and would not replace national patents or classical EPs ${ }^{24}$ - also uses the EPC patent granting system. Under this route, applicants would apply to the EPO for a patent in the countries requested. However, in contrast to the EPC system, if the patent is granted, applicants can then request that the patents for participating EPC states are designated as a "European patent with unitary effect" (EPUE). This would result in an "EPUE" which has unitary effect in the participating EPC states. To do so, applicants must file a request to the EPO for unitary effect within one month of the publication of the patent grant in the European Patent Bulletin. ${ }^{25}$

The unitary effect of the EPUE in participating states means that it has "equal effect in all participating Member States" and "should only be limited, transferred or revoked, or lapse, in respect of all the participating Member States" ${ }^{26}$ It is an EU right created by two EU regulations and central to its legal basis is the EU system of enhanced co-operation. To support this system, the UPP

21 See discussion in Jaeger, "Reset and Go", supra n. 15, part 4.2.

22 Regulation (EU) No 1215/2012 of the European Parliament and of the Council of 12 December 2012 on jurisdiction and the recognition and enforcement of judgments in civil and commercial matters [2012] OJ L 351/1.

23 Convention of 30 October 2007 on jurisdiction and the recognition and enforcement of judgments in civil and commercial matters [2007] OJ L 339/3.

24 Regulation 1257/2012, Recital 26.

25 Ibid., Recital 18.

$26 \quad$ Ibid., Recital 7. 
also created the UPCt, which has jurisdiction for all EPUEs beyond the transitional period, and also for all classical EPs in the states which have ratified the AUPC. ${ }^{27}$

As noted, although the UPP system was initially planned to include all EU Member States, however, agreement could not be reached, and it was decided to go ahead with the states who wanted to participate, using an enhanced cooperation scheme. ${ }^{28}$ Twenty-six EU Member States - every state except Croatia and Spain - participate in this enhanced co-operation scheme. However, whilst Poland participated in the enhanced co-operation scheme, it subsequently announced it would not sign or ratify the AUPC, and thus will not currently participate in the UPP. ${ }^{29}$ When and if, the UPP comes into operation, an EPUE can be applied for in the States which have ratified the AUPC. This means that depending on how many states have ratified the AUPC on the commencement of the system, one could initially have an EPUE for the seventeen states, eighteen states etc. However, the AUPC cannot take effect until it has been ratified by the UK, France, and Germany i.e. the three states with the greatest number of patents in the previous year. ${ }^{30}$ Thus, the UK's recent ratification was practically significant in terms of when the system can commence but we still await the

27 For a full overview of the system, see McMahon, supra n. 17, pp. 48-50.

28 As set out in Regulation 1257/2012.

29 '2017: Finally, the final steps towards the Unitary Patent system?' (Kluwer Patent Blogger, 10 January 2017) http://patentblog.kluweriplaw.com/2017/01/10/2017-finally-final-stepstowards-unitary-patent-system/ (accessed February 2018).

30 Art. 89 AUPC which reads: "(1) This Agreement shall enter into force on 1 January 2014 or on the first day of the fourth month after the deposit of the thirteenth instrument of ratification or accession in accordance with Article 84, including the three Member States in which the highest number of European patents had effect in the year preceding the year in which the signature of the Agreement takes place or on the first day of the fourth month after the date of entry into force of the amendments to Regulation (EU) No 1215/2012 concerning its relationship with this Agreement, whichever is the latest". 
outcome of the German constitutional complaint and whether it will ratify the system.

As an aside, the outcome and timing of Germany's ratification of the AUPC is important because the UPP system cannot take effect without this, and this is also significant for the UK's participation in the UPCt system. If the compliant is successful and Germany decides not to ratify the AUPC, the AUPC would then need to be amended to allow the system to continue without Germany - because it is one of the participating States with the greatest number of patents. This would take time and is unlikely to happen prior to $29^{\text {th }}$ March 2019. Moreover, even if the compliant is unsuccessful, the timing of Germany's subsequent ratification of the AUPC could be significant for the UK's participation in the UPCt system. The initial plan was for the UK to ratify the AUPC and for the UPCt system to be up and running before the UK leaves the EU on $29^{\text {th }}$ March 2019. If the system has not legally commenced by $29^{\text {th }}$ March 2019, further legal questions will be raised around the UK's position because as will be discussed entry into the UPCt system is only available to EU Members. This further uncertainty posed by the German compliant should be borne in mind in the discussion which follows.

Given this background, in terms of the UK's participation in the UPP postBrexit, the EPUE and UPCt must be considered separately as different issues arise. First, given the nature of the EPUE as an EU right and not an international one, which has as its legal basis two EU regulations, it is highly unlikely the UK could remain part of the EPUE post-Brexit. If the UPP system is in operation by the time the UK leaves the EU in March 2019 - which is dependent on what happens in the case of Germany ${ }^{31}$ - the regulations creating the EPUE are likely

31 The uncertainty around the timeline is discussed in "Unified Patent Court project at risk amidst uncertainties in the UK and Germany, says expert" (Outlaw Blog, 27 October 2017), 
to cease to have effect once the UK leaves the EU, unless relevant transitional measures are adopted. Therefore, unless the nature of the right itself is changed or an international agreement on this issue is possible and can be negotiated with other EU Member States, it is highly unlikely the UK will remain part of the EPUE element of the UPP package. At the time of writing, the UK government has also not given express assurances in respect of the UKs participation in the EPUE post-Brexit. ${ }^{32}$

Secondly, in terms of the AUPC, this is an international agreement and therefore given that the UK has already ratified this, it is likely to endeavour to adopt measures to ensure it can legally remain part of the UPCt system postBrexit. There are, however, challenges remaining in this respect, discussed below. Moreover, if the UK does this, post-Brexit it would likely be party to the AUPC and in the UPCt system, but not part of the EPUE. In practical terms, this would mean that patents with unitary effect (EPUEs) would not include the UK and instead would only be available for the other participating EU States. A national patent or classical EP would be needed to obtain patent protection in the UK. Moreover, in such circumstances, in the UK context the UPCt would only be involved and have jurisdiction for classical EPs which are valid in the UK. ${ }^{33}$

It is also questionable whether the further compromises which will be needed to allow the UK to participate in the UPCt post-Brexit and to bring the UPP system into effect are desirable given the shape of the currently proposed system. This is because the planned UPP system will give rise to multiple

available at https://www.out-law.com/en/articles/2017/october/unified-patent-court-projectat-risk-amidst-uncertainties-in-the-uk-and-germany-says-expert/ (accessed 1 February 2018).

32 Correct at the time of writing (May 2018). See also McDonagh, supra n. 9, p. 7. More generally, see also discussion in: Roger Green, “Unitary Patents almost a reality - UK signs the Unified Patents Court Agreement" (27 April 2018) https://www.lexology.com/library/detail.aspx?g=82b95121-c0f5-4737-9b7d-b347c01166de

33 See also McDonagh, supra n. 9, p. 7. 
avenues of patent protection and thus a further complicated and fragmented patent landscape. Applicants will still be able to apply for national patents through the national route in each state in which the patent is desired. Applicants will also be able to apply through the EPO for classical EPs in EPC states. However, the post-grant life for these patents would either be under the jurisdiction of the UPCt for states which have ratified the AUPC or would go to national states when the patent is applied for in states which are not participating in the AUPC namely Croatia, Poland, Spain, or states which cannot ratify the AUPC, i.e. other EPC states which are not in the EU. Applicants could also apply to the EPO for a patent and register it for unitary effect (that is, an EPUE) in the participating states. This landscape is further complicated given that there will be a transitional period of seven years after the AUPC comes into effect, and during this time applicants can choose to opt out of the UPP system, meaning that patents would fall under the consideration of the national state post-grant and not the UPCt. Furthermore, as demonstrated, the system is planned to come into effect once it has the requisite number of ratifications to the AUPC and, therefore, there could initially be an EPUE with just seventeen, eighteen states etc., depending on how many states have ratified the AUPC at a given point in time. Thus, one may initially be able to obtain an EPUE for a smaller number of states and EPs or national patents in the remaining states. ${ }^{34}$ Nonetheless, despite this complex and fragmented landscape created by the currently proposed UPP, the UK has recently ratified it.

However, significant future challenges are likely in this context, and it remains to be seen what will happen with the UK's role in the UPCt system postBrexit. In this vein, the UPCt is not a court of the EU; instead, it is described as

34 For an overview of the institutional complexity of the system, see McMahon, supra n. 17, pp. 51-52. 
being modelled on the Benelux courts, ${ }^{35}$ and described in the AUPC ${ }^{36}$ as : "a court common to the Contracting Member States and thus subject to the same obligations under Union law as any national court of the Contracting Member States" ${ }^{37}$ Nonetheless, although it is an international court and not an EU court per se, EU law nevertheless has primacy in decisions of the UPCt ${ }^{38}$ and safeguards to ensure this are embedded in the AUPC. For instance, the preamble to the AUPC states that the UPCt:

... as any national court, the Unified Patent Court must respect and apply Union law and, in collaboration with the Court of Justice of the European Union as guardian of Union law, ensure its correct application and uniform interpretation; the Unified Patent Court must in particular cooperate with the Court of Justice of the European Union in properly interpreting Union law by relying on the latter's case law and by requesting preliminary rulings in accordance with Article 267 TFEU. ${ }^{39}$

The preamble also confirms that Contracting States to the AUPC will be responsible for damages arising from an infringement of EU law by the UPCt, including a failure to refer preliminary rulings to the CJEU, and it states that infringements by the UPCt are directly attributable to the Contracting States. ${ }^{40}$ Moreover, the preamble refers to the Charter of Fundamental Rights, confirming that this is one of the sources of law applicable within the UPCt. ${ }^{41}$ The UPCt thus

35 Jan Brinkhof and Ansgar Ohly, "Towards a unified patent court in Europe" in Justine Pila and Ansgar Ohly (eds.) The Europeanization of Intellectual Property Law (Oxford: Oxford University Press, 2013), p. 211.

36 This is an international agreement between participating states and not an EU instrument.

37 Art. 1, AUPC.

38 Art. 20 AUPC.

39 Preamble, AUPC, p. 5.

40 Preamble, AUPC, p. 5.

41 See McMahon, supra n. 17, p. 58. 
has significant links with the EU legal order. Bearing in mind these features, the main challenges for the UK's participation in the UPCt system post-Brexit are considered in parts three and four.

\section{Roadblock I: The role of the CJEU in the UPP}

Because EU law has primacy within the UPP system ${ }^{42}$ to safeguard its application, the UPCt has links with the CJEU. For instance, Article 21 AUPC provides that decisions of the CJEU are binding on the UPCt. Moreover, the Court of First Instance and the Court of Appeal of the UPCt can make a preliminary referral to the CJEU and if they do so, a stay on proceedings before the UPCt will operate. ${ }^{43}$ There are limited EU laws concerning patents and limited substantive provisions in the regulations setting up the EPUE, which was intended to limit the CJEU's influence in this area. ${ }^{44}$ However, the Biotechnology Directive 98/44EC sets out substantive EU law governing patents on biotechnological inventions and EU regulations also apply in respect to supplementary protection certificates (SPCs) for medicinal ${ }^{45}$ and plant protection

42 Art. 20, AUPC.

43 Art. 38 of AUPC which states: "(1) The procedures established by the Court of Justice of the European Union for referrals for preliminary rulings within the European Union shall apply.

(2) Whenever the Court of First Instance or the Court of Appeal has decided to refer to the Court of Justice of the European Union a question of interpretation of the Treaty on European Union or of the Treaty on the Functioning of the European Union or a question on the validity or interpretation of acts of the institutions of the European Union, it shall stay its proceedings."

44 Some were critical of giving the CJEU a broader role in substantive patent law in the UPP and the original Arts. 6-8 of the draft regulation on unitary patent protection was removed in an attempt to limit the CJEU's interpretative role in this context. See Stjerna, supra n. 13, pp 4-5. See also Brinkhof and Ohly, supra n. 35, at p. 251, or Jacob R (2011) Opinion (2 November 2011), available at http://www.eplawpatentblog.com/2011/November/Robin\%2020Jacob\%2020Opinion\%2020re \%2020Arts.pdf (accessed 1 February 2018), at p. 3.

45 Regulation concerning the creation of a supplementary protection certificate for medicinal products (1768/92, 18 June 1992). 
products. ${ }^{46}$ Thus, the CJEU's influence is more directly evident in such fields. Moreover, doubts have been raised over the extent to which the CJEU's competence has in fact been limited in the operation of the UPCt and, particularly if gaps are left in the current legal framework for its operation, this could result in a broader reach of the CJEU in this context than initially conceived in patent circles. ${ }^{47}$ Furthermore, the interaction between patents granted by the UPCt and other areas of EU law, such as competition law ${ }^{48}$ and fundamental rights must be borne in mind as these aspects bring patent law, albeit indirectly, under the purview of the CJEU. This point is supported by considering that the Charter of Fundamental Rights is listed in the preamble to the AUPC as one of the sources which the UPCt can refer to. ${ }^{49}$

The role that the CJEU has in the functioning of the UPCt creates significant challenges for the UK's future in the UPP system, particularly because the Brexit whitepaper stated that the UK government intended to "bring an end to the jurisdiction of the CJEU in the UK" ${ }^{50}$ Given the role the CJEU has in the UPP system, the UK simply could not be part of the current system without acceding to its jurisdiction in this context post-Brexit. A potential avenue by which the UK could justify an exception for patent law is evident in the whitepaper, which stated that even though the CJEU's jurisdiction in the UK would end, "we will of course continue to honour our international

46 Regulation concerning the creation of a supplementary protection certificate for plant protection products (1610/96, 23 July 1996).

47 Stjerna, supra n. 13, p. 5. See also Thomas Jaeger, "Shielding the Unitary Patent from the ECJ: A Rash and Futile Exercise" (2013) 44(4) International Review of Intellectual Property and Competition Law 389-391; Winfried Tilmann, "The UPC Agreement and the Unitary Patent Regulation-construction and application" (2016) 11(7) Journal of Intellectual Property Law \& Practice 545-558.

48 Hugh Dunlop, "What now for the Unified Patents Court following the Brexit referendum?" (2016) 38(10) European Intellectual Property Review 595-597, p. 596.

49 See AUPC, Preamble. See also McMahon, supra n. 17, p. 58.

50 HM Government Whitepaper, supra n. 12, para 2.3. 
commitments and follow international law". ${ }^{1}$ The AUPC is an international agreement and not an EU instrument, and it was agreed upon prior to the Brexit referendum. Hence, it could be argued that the UK is merely maintaining this international commitment. The difficulty with this line of argument is that, unlike other international obligations, the operation of the UPCt as set out in the AUPC is directly tied to accepting the CJEU's role within the UPCt system, and it remains to be seen whether in the post-Brexit context it will be possible to negotiate an agreement on this for the UK and even if so, whether this will be politically palatable to the UK or other EU Member States.

Given that one of the aims of the UK government post-Brexit, as emphasised in the whitepaper, is "taking control over of our own laws" 52 and severing the control of the CJEU over domestic law, any suggestion of retaining this jurisdiction even in the field of patent law could be met with political resistance. Indeed, Douglas Carswell, a former member of the UK Independence Party (UKIP), ${ }^{53}$ tabled a motion on 9 February 2017 opposing the ratification of the "Protocol, done at Brussels on 14 December 2016, on Privileges and Immunities of the Unified Patent Court". ${ }^{44}$ This was accompanied by an online petition against the UK's ratification of the UPP. ${ }^{55}$ These attempts to halt the ratification attracted very minor support and ultimately, did not affect the practical passage of relevant legislative orders or the UK's eventual ratification

51 Ibid.

52 Ibid., para 2.

53 Carswell quit the UKIP party in March 2017. See “Douglas Carswell quitting UKIP to become independent MP for Clacton" (BBC News, 25 March 2017), available at http://www.bbc.com/news/uk-politics-39393213 (accessed 1 February 2018).

54 See https://www.parliament.uk/edm/2016-17/940 (accessed 1 February 2018). This attracted just one signature.

55 Available at http://techrights.org/2017/02/13/upc-petition-launched/ (accessed 6 December 2017) which had attracted 110 citizen signatures and 24 company signatures. 
of the AUPC on 26 April 2018. ${ }^{56}$ Nonetheless, even though the UK has now ratified the AUPC prior to Brexit, it remains to be seen how the role of the CJEU and EU law in the UPCt system will be addressed in future in order for the UK to participate in the AUPC post-Brexit.

\section{Roadblock II: The Unitary Patent Package - An EU- Members-only club?}

In this vein, to participate in the UPCt system, the UK would have to accept the role of the CJEU in this context, but even if did so, this would still not necessarily guarantee the UK's continued participation in the UPCt scheme post-Brexit. This is because the AUPC currently provides that the UPCt system is open only to EU members and it is questionable whether the system would be compatible with EU law if the UK - once it leaves the EU - is a participant.

In terms of the UPCt, Article 2(b) of the AUPC defines "Member State" as Member State of the EU, and "Contracting State" is defined in Article 2(c) as "a Member State party to this Agreement". This terminology clearly indicates that in its current form the UPCt is only open to EU Member States. As noted the UK as a current EU Member State was able to ratify the AUPC as it is still in the EU.

56 On 26 June 2017, the draft Unified Patent Court (Immunities and Privileges) Order 2017 was laid before Parliament in Westminster. It was debated and approved by the House of Commons on 4 December 2017, and the House of Lords on 12 December 2017. It was then approved by the Privy Council in February 2018. A similar Scottish order, The International Organisations (Immunities and Privileges) (Scotland) Amendment (No. 2) Order 2017, was approved by the Scottish Parliament on 25 October 2017. The UK's Foreign and Commonwealth Office deposited a formal letter signed by Boris Johnson, the Foreign Secretary with the General Secretariat of the Council of the European Union stating that the UK will be bound by the AUPC and the Unified Patent Court Protocol on Privileges and Immunities on 26th April 2018. See Alan Johnson, "UK ratifies the UPC Agreement" (26 April 2018) https://www.bristowsupc.com/latest-news/uk-ratifies-the-upc-agreement (accessed May 2018); See also: https://publications.parliament.uk/pa/cm201719/cmvote/171204v01.html (accessed 1 February 2018). 
However, the system cannot commence until Germany ratifies it and as noted this is currently delayed due to the German constitutional complaint against the AUPC. It is therefore unclear whether the UPCt will come into force before the UK leaves the EU in March 2019. Moreover, even if it does, as noted questions remain about the UK's continued participation in the UPCt system or EPUE postBrext.

Once the UK officially leaves the EU - after the two-year negotiation period started by the procedure set out in Article 50 of the Lisbon Treaty - absent relevant transitional measures being adopted, the two EU regulations establishing the EPUE will cease to apply in the UK. Therefore, without other international agreements, the UK's entitlement to participate in the EPUE element would also cease, given that these regulations set up the scheme for granting and recognising unitary patents. ${ }^{57}$

Moreover, to safeguard its continued participation in the UPCt, the UK would need to negotiate and agree appropriate international agreements with other Contracting States involved in the AUPC, and the AUPC would need to be amended to expand the definition of member to include the UK as a non-EU state. However, most importantly, any agreement would have to safeguard the primacy of EU law in the UPCt system, ${ }^{58}$ otherwise it could be deemed incompatible with EU law.

Opinion 1/09 of the CJEU delivered on 8 March 2011 is instructive in this context as therein the CJEU held that an earlier iteration of a unified patent

57 See Richard Gordon QC and Tom Pascoe, Brick Court Chambers, "Opinion re the Effect of 'Brexit' on the Unitary Patent Regulation and the Unified Patent Court Agreement" (12 September 2016). For alternative arguments see Wouter Pros, "The Unified Patent Court Back on Track Again" (Two Birds, 29 November 2016), available at https://www.twobirds.com/en/news/articles/2016/global/unified-patent-court-back-on-trackagain (accessed 1 February 2018).

58 Gordon and Pascoe, supra n. 57, paras. 50 and 52. 
litigation system which included EU and non-EU states party to the EPC was incompatible with EU law. The Opinion did not expressly state that a unified patent system would only be compatible with EU law if it involved EU Member States. Nonetheless, the membership of non-EU states in a unified patent system was not the specific question the CJEU was tasked with in Opinion 1/09. Thus, whilst the Opinion does not expressly preclude non-EU Member States from being party to the UPP, there is nothing to guarantee that the CJEU would not reach this conclusion in a future case. At the very least, for the UK's post-Brexit participation in the UPCt system - in its current form - to remain compatible with EU law, it would have to ensure safeguards for the protection of EU law are evident to address issues raised in this context by Opinion 1/09.

The section below critically examines Opinion 1/09, highlighting: 1) the statements in Opinion 1/09 which could be used to argue against non-EU states, including the UK's (post-Brexit) participation in the UPCt system, and 2) that even if the UK were to surpass this issue, minimum safeguards for EU law would have to been adopted by the UK to ensure its post-Brexit participation in the UPCt system addressed concerns raised in Opinion 1/09 and was compatible with EU law.

\subsection{Opinion 1/09 - Obstacles for the UK's post-Brexit role in the UPCt as a non-EU state}

In Opinion 1/09 the CJEU considered a proposal for the creation of a "Community patent" which would be granted by the EPO. The Community patent would have "equal effect throughout the whole European Union, and could be granted, transferred, declared invalid or lapse in respect of that 
territorial area" ${ }^{59}$ It was also intended to include an "international agreement to be concluded between the Member States, the European Union and third countries which are parties to the EPC... creating a court with jurisdiction to hear actions related to European and Community patents," 60 the "European and Community Patents Court" (PC). The CJEU was tasked with considering whether the planned agreement creating this unified patent litigation system was compatible with provisions of the Treaty establishing the European Community. ${ }^{61}$

The CJEU held it was incompatible with EU law for several reasons, including: (1) the PC would not be part of the EU legal order and not part of the judicial framework within the EU, ${ }^{62}$ yet despite this would have to interpret EU law; ${ }^{63}$ (2) relatedly, it would deprive national Member States of their jurisdiction to decide certain aspects of patent law, as the PC would have exclusive jurisdiction in certain areas. ${ }^{64}$ This would also deprive national courts of their task of implementing EU law and there would be no way to ensure harmonisation of EU law which is generally provided for by the EU's preliminary referral procedure to the CJEU. The draft agreement allowed for preliminary referrals to the PC but removed this power from national courts; ${ }^{65}$ and (3) if the PC was found to be in breach of EU law, the decision would not be capable of being subject to infringement proceedings under EU law, or claims in damages against EU Member States. ${ }^{66}$ Thus, proceedings for enforcing compliance with

59 Opinion $1 / 09$, para. 6.

$60 \quad$ Ibid., para. 7.

$61 \quad$ Ibid., para. 1.

62 Ibid., para. 71.

63 Ibid., para. 78.

64 Ibid., para. 79.

65 Ibid., paras. 80-83.

66 Ibid., para. 86. 
EU law were absent. ${ }^{67}$ Following this opinion, the draft agreement to create a unified patent system was amended which led to the current UPP system which does not include non-EU states.

Notably, following the issuance of Opinion 1/09, the EU's Commission Services issued a paper examining possible solutions for creating a unified patent system in which it stated that the effect of Opinion 1/09 was to exclude membership of third States, ${ }^{68}$ i.e. non-EU states. This view does not come from the CJEU, and therefore it is not binding. It has also been strongly criticised as a "misguided" reading of Opinion 1/09,69 and is certainly a very narrow reading of it. Nonetheless, the revised UPP, following Opinion 1/09, was only open to EU Member States despite the original plan to create a system to include all EPC states - and it is questionable why attempts were not made to address concerns raised by Opinion 1/09 in a way which would also have allowed non-EPC states to remain party to the system. Modifying the system to include only EU Member States was arguably considered the easiest route to address concerns raised in Opinion 1/09, however, the extent to which these concerns are effectively

${ }^{67}$ See also discussion of the reasons for the finding of incompatibility with EU law in Gordon and Pascoe, supra n. 57, para. 14.

68 See Note from the Presidency to the Council Doc 10630/11, Annex II "Solutions for a Unified Patent Litigation System - The way forward after the Opinion 1/09 of the CJEU, Non Paper of the European Commission", available at http://register.consilium.europa.eu/doc/srv?l=EN\&f=ST\%2010630\%202011\%20INIT (accessed 1 February 2018) which states at Annex II, p. 7 that: "As a result of opinion 1/09 of the CJEU, it appears that the participation of third countries must be excluded" and, at p. 10, "As set out above, on the basis of the opinion of the CJEU, third states may not participate in this agreement."

69 Jaeger, "Reset and Go", supra n. 15; Thomas Jaeger, "Back to Square One? - An Assessment of the Latest Proposals for a Patent and Court for the Internal Market and Possible Alternatives" (2012) International Review of Intellectual Property and Competition Law 286, p. 296. 
addressed, and to which the current proposal is compatible with EU law, remain subject to question. ${ }^{70}$

Nonetheless, several statements in Opinion 1/09 demonstrate that non-EU states' membership of the UPP system would be open to challenge in terms of compatibility with EU law, and this in turn would depend on the guarantees for EU law present in any such system. For instance, the CJEU noted that EU MSs are obliged by reason of "the principle of sincere cooperation, set out in the first paragraph of Article 4(3) TEU, to ensure, in their respective territories, the application of and respect for European Union law" ${ }^{\prime 7}$ Furthermore, it stated that: "[t]he national court, in collaboration with the Court of Justice, fulfils a duty entrusted to them both to ensuring that in the interpretation and application of the Treaties, the law is observed"72 and later that " $[t]$ he judicial system of the European Union is moreover a complete system of legal remedies and procedures designed to ensure review of the legality of acts of the institutions."73 Following the UK's withdrawal from the EU, and without further transitional or other agreements being put in place to the contrary, the UK would be outside the EU judicial system therefore the legal remedies and procedures designed to ensure legality of EU law would not bind the UK. It would also not have a duty of "sincere cooperation" once it ceased to be a national EU Member State. Hence, these safeguards would not apply, and the criticisms raised in Opinion 1/09 against the PC proposal, could therefore also be raised against the UPP system with the UK as a participant in it post-Brexit.

Furthermore, the CJEU in Opinion 1/09 stated that the planned PC could be distinguished from the Benelux Court as:

\footnotetext{
70 Jaeger, "Reset and Go", supra n. 15, p. 273.

Opinion 1/09, para. 68.

2 Ibid., para. 69.

73 Ibid., para. 70.
} 
the Benelux Court is a court common to a number of Member States, situated, consequently, within the judicial system of the European Union, its decisions are subject to mechanisms capable of ensuring the full effectiveness of the rules of the European Union. ${ }^{74}$

In the currently proposed UPP, the UPCt has been designed as a court common to member states of the EU and akin to the Benelux court to address this point. ${ }^{75}$ However, if the UK were a participant of the UPCt system post-Brexit it would change the position of the court as it would no longer be a court common to EU Member States given that the UK would then fall outside the EU legal order. This would raise further questions on the compatibility with EU law of the currently proposed system and could increase the likelihood of the UPCt system being challenged before the CJEU after it comes into effect.

\subsection{Opinion 1/09 - Minimum safeguards to ensure compatibility with EU law}

Nonetheless, it has been argued by Gordon and Pascoe $^{76}$ that the UK could potentially continue to participate in the AUPC and therefore UPCt system postBrexit provided it adopted safeguards for EU law in the patent field to address Opinion 1/09. To do so, at a minimum the UK would need to ensure: (1) the primacy of EU law in the operation of the system in the UK. In this vein, Gordon and Pascoe argue it would be necessary for the UK to ensure EU law is accepted in "its entirety"77 in patent disputes under the jurisdiction of the UPCt for

$74 \quad$ Ibid., para. 82 .

75 This has been criticised by Jaeger, who argues that the extent to which the proposed UPCt embodies the features of a Benelux type court is questionable, given the lack of links between the UPCt and national courts, amongst other features. See Jaeger, "Reset and Go", supra n. 15, p. 273.

76 See also Gordon and Pascoe, supra n. 57, paras. 72-102.

77 Ibid., para. 76 . 
example by accepting relevant EU competition law, fundamental rights etc., alongside substantive EU patent provisions, for example the Biotechnology Directive; (2) a system of preliminary referral for patent law would be necessary to ensure the harmonised interpretation of EU law. This would require careful consideration of EU law on preliminary referral procedures currently set out in Article 267 TFEU which provides that the CJEU has jurisdiction to give such rulings where questions are raised by a "court or tribunal of a Member State". ${ }^{78}$ The UK would cease to be a Member State of the EU at the end of its withdrawal from the EU so the CJEU would not have jurisdiction under Article 267 to accept referrals from the UK. However, Gordon and Pascoe argue that subject to an international agreement which the Union was party to, the CJEU could be vested with jurisdiction to accept preliminary references from the non-EU states' courts; ${ }^{79}$ (3) finally, there would need to be a way to ensure the UK could be subject to infringement proceedings for failing to comply with EU law in this context, to ensure that private parties can obtain damages for breaches. The CJEU only has jurisdiction to hear infringement actions against EU Member States under arts. 258, 259, and 260 TFEU. ${ }^{80}$ Again Gordon and Pascoe argue that the jurisdiction of the CJEU could be expanded by way of an international agreement between the EU and the UK as a non-EU state ${ }^{81}$ and, if it were, a provision could be included to address the infringement issue.

If adopted, these measures could help to safeguard the UK's place in the UPCt system post-Brexit by ensuring it is compatible with EU law. However,

78 Ibid., para. 84.

79 Gordon and Pascoe, supra n. 57, para. 86. Art. 16(2) of the ECAA (European Common Aviation Area Agreement) provides a precedent for this and the authors argue that a similar argument could be used to allow the UK to participate in the UPP.

$80 \quad$ Ibid, para. 78.

81 Ibid., paras. 80 and 86. 
these measures are likely to be difficult to negotiate and implement, and it is highly questionable whether they would be politically palatable for the UK or for other EU Member States considering the broader context of the Brexit debate. Moreover, the relevant agreements and amendments to the AUPC which would be required would likely take considerable time to conclude and to implement.

Furthermore, given the statements highlighted from Opinion 1/09 and the previous narrow reading of that Opinion by the Commission, after the UK leaves the EU if it is in the UPCt system and this system has commenced, the compatibility of the system with EU law would almost inevitably be challenged before the CJEU. Based on the foregoing, if a narrow reading of Opinion 1/09 was applied, the CJEU could likely find the UK's participation post-Brexit - as a nonEU state - of the UPCt incompatible with EU law. Indeed, Gordon and Pascoe also expressly acknowledge this point stating, in their view, that it

would be constitutionally possible for the UK to continue to participate in the UPCA after "Brexit", so long as it signs up to all of the provisions of the Agreement which protect EU constitutional principles. However, there is a risk that the CJEU would reach the opposite conclusion. ${ }^{82}$

Moreover, it is important to consider whether all these further compromises which would be required for the UK to continue to participate in the UPCt postBrexit are worthwhile. Arguably, instead of focusing on how to position the UK in such a way as to allow continued participation, we should be thinking about whether the rules for participation and current shape of the UPP scheme needs to be changed to offer a more inclusive unitary patent system. If we are considering solutions to enable ongoing UK participation in the UPCt system

82 Ibid., para. $134(\mathrm{~b})$. 
post-Brexit when it will be a non-EU Member State, surely, it would be more prudent to consider alongside this how other non-EU States who are party to the EPC could also participate in the current UPP or a similar but reconfigured unified patent system.

\section{Consequences of UK non-participation in the UPP}

The foregoing has demonstrated some of the main hurdles which remain for the UK's participation in the UPP post-Brexit. This issue has significant implications, because if the UPCt or EPUE were to go ahead in their current form without the UK participation post-Brexit, this would have adverse consequences both for the UK and the UPP system more generally.

Four main consequences can be identified in this context. Firstly, looking to practical consequences from a UK perspective, the central division of the UPCt responsible for human necessities, ${ }^{83}$ chemistry, and metallurgy is currently set to be based in London, ${ }^{84}$ with the two other branches based in Munich and Paris. The UK IPO has already leased a space to host this branch, ${ }^{85}$ and has advertised for judges to sit there. ${ }^{86}$ However, given the UK is leaving the EU questions have been raised on whether it should retain this seat of the UPCt and other locations,

83 As defined by Section A WIPO International Patent Classification of WIPO sections which includes pharmaceutical, foodstuffs, agriculture, personal or domestic articles, and also medical devices, implements for diagnosis surgery, see generally: WIPO definition of Human Necessities -

http://web2.wipo.int/classifications/ipc/ipcpub/?notion=scheme\&version=20170101\&symbol= none\&menulang=en\&lang $=$ en\&viewmode $=\mathrm{f} \&$ fipcp $c=$ no\&showdeleted $=y e s \& i n d e x e s=$ no\&he adings $=$ yes\&notes $=$ yes\&direction $=02$ n\&initial $=A \& c w i d=$ none\&tree $=$ no\&searchmode $=$ smart (last accessed February 2018).

84 Art. 7(2), Agreement on Unified Patent Court.

85 Clive Cookson, "Britain to ratify single European patent system" (Financial Times, 28 November 2016).

86 Eanna Kelly, "EU will find a way to keep UK in unitary patent says EPO chief" (Science Business, 7 March 2017), available at https://sciencebusiness.net/news/80167/EU-will-find-away-to-keep-UK-in-unitary-patent\%2C-says-EPO-chief (accessed 1 February 2018). 
including Milan, ${ }^{87}$ have been discussed as an alternative. If the Central Division of the UPCt moved to another country in future, this would give rise to a considerable loss of legal and advisory work associated with patent litigation in this court. The loss of revenues to the UK if the London branch was moved to another country were estimated in 2012 to be in the range of $£ 545-£ 1,936$ million per year. ${ }^{88}$ There would also be indirect losses, including of expenditure from court employees and others associated with the court in London, ${ }^{89}$ and it would result in costs for UK clients to travel to another location to access the Central Division.

The EPO has stated that the London branch will go ahead because the UPCt is not an EU agency..$^{90}$ Rather, it is an international court formed outside the EU legal framework. This contrasts to the position of the European Medicines Agency and European Banking Authority which will be relocated by the Brexit deadline. ${ }^{91}$ However, Benoit Battistelli, President of the EPO, has been reported as stating that "nobody knows" what will happen to the London branch in the future, since whilst legally it could remain in London because it is not an EU

87 "Seat Central Division Unified Patent Court cannot be outside EU" (Kluwer News Blog, 2 February 2017), available at http://kluwerpatentblog.com/2017/02/02/seat-central-divisionunified-patent-court-cannot-be-outside-eu/ (accessed 1 February 2018); Mathew Field, "'Milan is a natural candidate': Italian IP lawyers target London Patents court post Brexit" (Legal Business Blog, 4 October 2016), available at http://www.legalbusiness.co.uk/index.php/lb-blog-view/7697-milan-is-a-natural-candidateitalian-ip-lawyers-target-london-patents-court-post-brexit (accessed 1 February 2018).

88 FTI Consulting, "Economic Impact of Alternative Locations for the Central Divisions of the Unified Patent Court" (28 May 2012), available at http://www.citysolicitors.org.uk/attachments/article/115/20121019-UPC-location-reportversion-for-publication-30-May-2012.pdf (accessed 1 February 2018), para. 1.4.

89 Ibid., paras. 1.6-1.8.

90 See Jorge Valero, "EU patent court to remain in London despite Brexit...for now" (EurActiv, 19 June 2017), available at https://www.euractiv.com/section/uk-europe/news/eu-patentcourt-to-remain-in-london-despite-brexit-for-now/ (accessed 1 February 2018).

91 See Laurence Peter, "EU prepares to move two agencies from London" (BBC News, 23 June 2017), available at http://www.bbc.com/news/world-40381320 (accessed 1 February 2018). 
agency, from a political and economic point of view it could be a different matter..$^{92}$

Furthermore, the legal issues with retaining the London branch are also uncertain, because whilst the UPCt is an international court, as discussed in part 5 above it has links with the CJEU, and EU law has primacy in its functioning. Thus, it would lead to the unusual position that a State which is not party to the EU would host a branch of the UPCt which would apply EU law in its functioning. Furthermore, although there is limited substantive EU law in the regulations setting up the UPP, existing EU law such as the Biotechnological Directive 98/44EC and regulations ${ }^{93}$ on supplementary protection certificates (SPCs) - the latter regulations on SPCs do not apply to unitary patents, however the European Commission is currently working on articulating SPC protection for unitary patents ${ }^{94}$ - bring matters under the purview of EU law. Given that the London branch deals specifically with pharmaceuticals and human necessities, it is likely to have a role in such areas falling within substantive EU law.

Secondly, in terms of consequences for patent applicants, if the EPUE proceeds without the UK being party to it, this will retain higher costs for those seeking a patent in the UK and other EPC states, which the EPUE was designed to reduce. This is because if the UK is not in the EPUE, applicants would have to follow the traditional route of seeking a patent from the EPO - also required in

92 Valero, supra n. 90.

93 Council regulation (EEC) No 1768/92 concerning the creation of a supplementary protection certificate for medicinal products (codified as Regulation (EC) no 469/2009 of the European Parliament and of the Council of 6 May 2009 concerning the supplementary protection certificate for medicinal products); Regulation (EC) No 1610/96 of the European Parliament and of the Council concerning the creation of a supplementary protection certificate for plant protection products.

94 See "Supplementary Protection for Unitary Patents", available at https://ec.europa.eu/growth/industry/intellectual-property/patents/supplementaryprotection-certificates en (accessed 1 February 2018). 
the EPUE context - but they would then have to separately validate this patent in the UK, rather than having this included in an application, for the patent to have unitary effect. This would entail legal fees for validation in the UK. Furthermore, unlike the classical EP system, the EPUE patent involves payment of one renewal fee, but if the UK was outside this system the renewal fees would also be separately owed to the UK if a patent was sought there. Thus, applicants who sought patents in the UK and other EPUE states would face greater costs as they would have to (1) pay to validate the patent in the UK alongside requesting unitary protection or validating the patent in other EPC countries; and (2) pay renewal fees post-grant in the UK and for the EPUE and/or other countries not participating in the EPUE, including non-EU States in the EPC.

In effect, the foregoing highlights that the UK and patent applicants would lose out on benefits which were deemed to arise from the UK joining the EPUE, as outlined in the UK Impact Assessment for the Unitary Patent. ${ }^{95}$ That document highlighted reasons for joining the UPP as including the time consuming and burdensome nature of the existing classical EP route for those seeking patents across Europe ${ }^{96}$ and the fact that costs of patenting in Europe far exceed costs in the US given the multiple patent renewal fees, validation and translation costs in Europe. ${ }^{97}$ Accordingly, some patent applicants could be discouraged from patenting in the UK due to continuing high costs of renewal and the lack of a streamlined process. This is, however, less likely for larger patent applicants given the size of the UK market and benefits arising from entry to it.

\footnotetext{
95 "Impact Assessment, Unified Patent Court Implementation - Unitary Patent" (26 March 2014), available at https://www.gov.uk/government/uploads/system/uploads/attachment data/file/317641/IA UPC Implementation Unitary Patent.pdf (accessed 1 February 2018).

96 Ibid., p. 4.

97 Ibid.
} 
Thirdly, if the UK is unable to participate in the EPUE or UPCt system post-Brexit, this would have knock-on consequences for the system in general. The proposed UPP was an attempt following longstanding debate to reduce postgrant fragmentation in the European patent system. However, over time it has morphed into a much-reduced unification of patent law in Europe than that which was originally advanced. Initially, proposals attempted to garner agreement for a European patent system including all 38 EPC states, but this met with significant hurdles and was eventually abandoned. Subsequently, a system for all EU Member States was planned, but again agreement could not be reached. The resulting debate led to the current UPP, which is open to all EU Member States who wish to participate (not all of whom have joined) but is not open to non-EU states. Thus, the UPP is a product of many years of debate, but it is neither the streamlined post-grant process nor the unification of European patenting which many had desired. ${ }^{98}$ If the UK post-Brexit is not party to the UPP, or party to the UPCt but not in the EPUE, this reignites questions as to whether this system in its current form is desirable or if it is simply a compromise too far. ${ }^{99}$

Fourthly, it is questionable whether the EPUE will be as economically feasible if the UK, one of the states with the largest number of patents granted in Europe, is not party to the system. For some patent applicants, depending on how many European states they wish to patent in, it may be more attractive to go down the national patenting route rather than seek an EPUE and validate a patent in the UK and other EPC countries which are not in the EU. Moreover, the renewal fees for the EPUE were calculated under the presumption that the UK

98 It has been argued elsewhere the system is likely to increase fragmentation at a supranational level. See McMahon, supra n. 17.

99 See generally "The Unitary Patent system has become an emergency patchwork" (Kluwer UPC News Blogger, 17 January 2017) http://kluwerpatentblog.com/2017/01/17/unitarypatent-system-become-emergency-patchwork/ (accessed 1 February 2018). 
would be party to the system, and these may need to be reconsidered if this is not the case.

\section{Conclusion}

There are still uncertainties and hurdles ahead for the UK's participation in the currently conceived UPP post-Brexit. To remain party to the UPCt system in its current form, the UK would have to accede to the jurisdiction of the CJEU in this context post-Brexit and an international agreement would have to be concluded to this effect between it and the EU. It would also have to negotiate modifications of the AUPC to change the definition of "member" to accommodate the UK's position once it leaves the EU. Furthermore, it would need to adequately guarantee protections for EU law in order to address issues raised by Opinion 1/09 for when it is no longer an EU Member State. However, reaching such agreements is likely to be a difficult and time-consuming process. There is also likely to be political resistance to such moves given the broader context of the Brexit debate.

Moreover, even if such agreements were concluded the resulting system could still be challenged before the CJEU, which would then need to expressly consider whether the UPCt system is compatible with EU law if the UK as a nonEU state is a participant in it. As demonstrated above, the reasoning in Opinion 1/09 means that much would depend on the safeguards for EU law which were embedded in the system. Moreover, if the UK's post-Brexit participation in the UPCt system was deemed compatible with EU law, this would raise the question of whether other non-EU states party to the EPC should not also be allowed to join the AUPC or if not, on what basis these States should be distinguished from a post-Brexit UK in this context. 
Given these current obstacles, and the fragmented landscape of patent protection which is emerging, this article argues that it would be more desirable to reconsider the current unitary patent proposal as a whole in order to reconfigure it to develop a more inclusive package including all EPC States. Ideally, this would provide for a system that reduces fragmentation and provides for a unitary patent system for all EPC States or at least more than the current 25 EPC states who have indicated they will participate in the UPP (assuming the UK's continued participation). ${ }^{100}$ Moreover, whilst only time will tell whether Brexit marks the end of the road for the UK in the UPCt system and the EPUE, the odds are currently stacked against the UK certainly in terms of the EPUE and questions also remain for its role in the UPCt.

100 This article echoes calls from others, including Jaeger, that Brexit be considered an opportunity "to remedy the flaws of the all-too quick modifications to the 2009 model after Opinion 1/09 and to bring non-EU EPC states back on board." See Jaeger, "Reset and Go", supra n. 15, p. 273. 